\title{
Problems Analysis of Calculus Learning in Higher Educations
}

\author{
$1^{\text {st }}$ Khairani \\ Mathematics Department \\ Universitas Negeri Padang \\ Padang, Indonesia \\ khairani@fmipa.unp.ac.id
}

\author{
$2^{\text {nd }}$ Mukhni \\ Mathematics Department \\ Universitas Negeri Padang \\ Padang, Indonesia \\ mukhniajoo@yahoo.co.id
}

\author{
$3^{\text {rd }}$ Faizah Qurrata Aini \\ Chemistry Department \\ Universitas Negeri Padang \\ Padang, Indonesia \\ faizah_qurrata@fmipa.unp.ac.id
}

\begin{abstract}
Calculus is one of course that is learned in college. It is an advanced mathematics subjects that had been learned by college students when they were in high school. College students must master calculus course in order to take higher courses which is an application of calculus concepts. But, in fact, many college students found problems in calculus learning. Purpose of research was to describe problems that happened in calculus learning. Type of research was descriptive research with qualitative approach. Data was collect from answer sheet, questionnaire and interview. The findings will be used for advanced research.
\end{abstract}

Keywords-calculus learning, college students, problems analysis, qualitative approach

\section{INTRODUCTION}

Calculus in one of main course in higher education. It is not only lectured in mathematics major but also in others major, such as medicine, engineering, computer science, applied medical science and science because its application has benefit in every aspects in every life [1]. Derivative concepts can be used to understand the regenerations of viruses and bacteria in medicine field and biology major. Regenerations speed of cancer cells also can be modeled in function with calculus concepts so it can be predicted how far the cancer cells can spread in human body. Calculus also can model the dosage of X-ray in chemotherapy to function so it can get the best dosage for patients of cancer. In engineering and technic engineering faculty, students must master calculus. Calculus is main gateway and foundation in engineering career [2]. Concept of limit often used in engineering and physic major. In other words, college students must master calculus because it is a ground theory to others course in college. It makes calculus as a course that is pushed to students by university. They must study calculus even though they are not in STEM major [3].

Despite the benefit of concepts calculus to others course in college, there were many students who failed in calculus course and had negative experience with calculus. A research at San Diego state in USA gave result that $12.5 \%$ students who had taken calculus course in STEM major at first year, switched their major in second year. It was $31.4 \%$ students who had switched major said that they had negative experience with calculus and calculus was main reason that caused they switched major [4]. That research showed that students found difficulties in calculus learning. They had bad attitudes towards calculus and it caused they did want to enrolled in STEM major further more. They wanted to get "free" from calculus so they took decision to switch major in university. It was not only happened in university of San Diego, it also happened in Universitas Negeri Padang.

All student colleges of Mathematics and Sciences Faculty in Universitas Negeri Padang must took calculus course in their first year in university without exception. Students in Biology major must took calculus course as well as students in Mathematics major and so Physics also Chemistry students. Even though college students had been studied basic calculus as mathematics subject in high school, they did not understand calculus concepts in university. Their test got bad mark and many students failed in calculus course. It made them take calculus course again in second years and they could not take course that used calculus as its foundation, example if student failed in calculus course, that student could not take advanced calculus course in mathematics major. It makes students spent more time to finish the study. There were many problems that had faced by students in calculus learning. This research had goal to describe problems that happened in calculus learning. If problems in calculus learning can be found, it can be good reference to find exact solution in order to increase the quality of calculus learning.

\section{METHODS}

Type of research was descriptive research with qualitative approach. Samples of research were 29 students who took calculus course in semester January-June 2018. Samples were done by purposive sampling. Instruments of research were answer sheet, questionnaire and interview.

\section{A. Answer Sheet}

All students in Mathematics and Science Faculty of Universitas Negeri Padang took the test which had been made by Faculty Committee. Test consisted of essay problem and must be solved in two hours. Students answered the problem in answer sheet. They must solve the problem and wrote procedure of problem solving in answer sheet. Data about students' understanding and problems in calculus learning could be gotten by analyzing the answer sheet.

\section{B. Questionnaire}

Open questionnaire was used in this research. Students were given a questionnaire that was consisted few open question. Students wrote their answer based on their sight and perception. So it could get different answer from each 
student. After that, the answer would be analyzed in accordance with the question. The questionnaire was given to students after they had taken final semester exam.

\section{Interview}

Aim of interview was to explore motivation, belief and thinking of individual about certain matters. This research used semi-structured interview. There was no rigid adherence in this interview. First, topic and question were listed by the depth of matters and then the question was asked to interviewee. Interview were done by asked the topic that made interviewee interested and then by the conversations continue interviewer asked about complex topic that was related to research [5]. Interview were done in this research because interview could be powerful method to get interviewee's perception and sight and it could also be used with other method (questionnaire) to get depth information about value and belief from interviewee [6].

\section{RESULT AND DISCUSSION}

Data which had been collect from answer sheet, questionnaire and interview, were analyzed by using qualitative approach. The data analyzing of each instrument were presented below:

\section{A. Analysis of Test Sheet}

Data of answer sheet were checked one question by one question and paid attention to students procedure in solving the problems. One of student's answer on calculus questions were shown in Fig. 1 below.

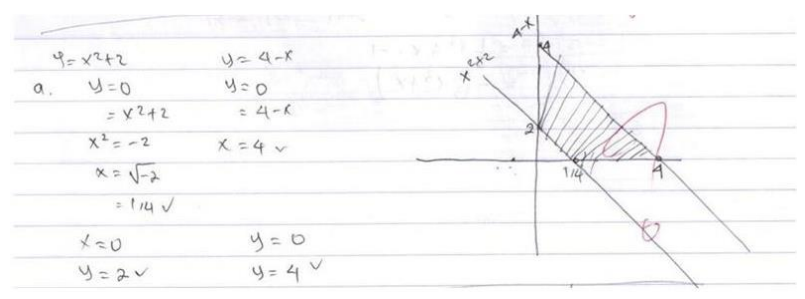

Fig. 1. Example of student's answer sheet

That question asked student to graph area D which was between graph function $y=x^{2}+2$ and $y=4-x$. Graph of area D could be got by graphing every point from domain and range of each function in Cartesius coordinate. But, student did not understand the concept of domain, range and graph of function. It caused student did not answer question correctly. This type of mistake also had been found in many students' answer sheet.

Another mistake that was done by student was shown in Fig. 2 below:

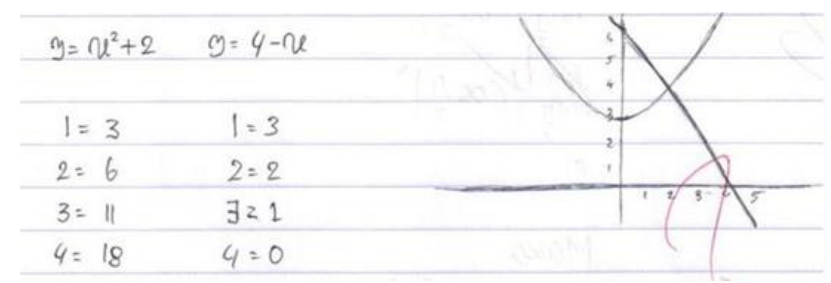

Fig. 2. Example of student's answer sheet
Another student answered the same question with false procedure in order to find domain and range of function. Student could not write mathematics notation correctly so $\mathrm{s} /$ he could not get right answer. But, from that answer sheet showed that student knew procedure to graph function but she or he did understand the concept of calculus.

\section{B. Analysis Questionnaire}

It was used open questionnaire in this research. There were a number of questions about calculus learning process, topic of calculus, students' understanding, and mark in calculus course. Students gave different answer based on their though and belief in calculus.

Data of questionnaire showed that about $93 \%$ students said that calculus learning process were good but there was one student said that calculus learning process was a little boring because it always saw formula and number also always got task after the class was over. There was student said that studied calculus in midday made she or he did not concentrate because class was so hot. It also showed that about $60 \%$ students said topic of calculus were difficult to understand. But, almost all of them agreed that calculus was advanced mathematics subject when they were in high school. A number of students even knew that if they had good basic mathematics in high school, they could get understand calculus in college. Many students said that trigonometry, limit, derivative, and integration were difficult topic in calculus course. Answer in questionnaire showed that all students really had high hope to get good mark but there were only a number of student said that the way to get good mark were by studied hard and did exercise of calculus.

\section{Analysis of Interview}

The interview were done after students took final exam. It was used semi structured interview. The topic and questions were listed before interview started and been asked to interviewee from interested topic to the complex one. The transcript below was the interview from Student A. He got good result in calculus course.

Lecturer : what is the problem that you face in mid semester exam?

Student A : I came late to class in test time. It made me panicked. So, my memorizing material had been gone and I got blank in the exam.

Lecturer : Did you study before take the exam?

Student A : I studied before took the exam but it was not really often because I had many task in others course. So, I could not really get understand the material.

Lecturer : Because of that, you got not very good mark in mid semester test. But, if it compared to final semester test, you got very good mark. What is the difference in your study when you facing mid semester exam and final semester exam?

Student A : I had feeling that my mark in Mid semester exam was not really good. So, I studied hard at home to face final semester exam. I also done all of exercises that Miss gave to us in 
classroom. If, I did not understand the concept I would ask Miss in the class. I also studied with my friend who in Mathematics major. He help me to solve the problem which I did not understand.

Lecturer : Oh, you have motivation to study Calculus?

Student A : In fact, I wanted to joint in Mathematics major. I had mathematics major as my first choice and Science as my second choice in selection exam. But, I failed in first choice and passed in my second choice. So, here I am now in science major. But, I really like mathematics so it make me motivate to study calculus in college.

Lecturer $\quad$ : Your positive attitudes toward mathematics give you good result because now you get good mark in calculus course.

Student A : Alhamdulillah Miss.

Lecturer : While having mid semester exam, what topic in calculus that you do not understand?

Student A : I do not understand implicit differentiation. It is new topic in college. I did not study it in high school. It makes me not really understand about the concept.

Lecturer : There is another topic?

Student A : I also found that it is difficult to find monotonicity and concavity of function. It gone black when I took the exam.

Lecturer : How about in final semester exam? What topic that you did not understand?

Student A : I did not understand integration of rational function using partial fractions. It gone blank when I took the exam. I also did not answer correctly the question about partial integration because I did not have enough time.

That interview showed that student had good motivation intrinsic and he could success in calculus course. It was also found that student had schedule to learn calculus at home and the topic he did not understand were monotonicity and concavity of function and integration of rational function using partial fractions. There were only two students who got very good mark.

The interview transcript below was gotten from student B who passed calculus course but she did not get good mark.

\begin{tabular}{|c|c|}
\hline Lecturer & $\begin{array}{l}\text { What topic in mid semester exam that } \\
\text { you did not understand? }\end{array}$ \\
\hline Student B & $\begin{array}{l}\text { I did not understand monotonicity and } \\
\text { concavity of function. }\end{array}$ \\
\hline Lecturer & $\begin{array}{l}\text { : In Final semester exam, what topic that } \\
\text { you did not understand? }\end{array}$ \\
\hline Student B & $\begin{array}{l}\text { I did not understand questions about } \\
\text { integrations. I did not know what } \\
\text { technique that was used to solve the } \\
\text { problem. I only used integration by part, } \\
\text { the only technique of integration that I }\end{array}$ \\
\hline
\end{tabular}

$\begin{array}{ll} & \text { understood. } \\ \text { Lecturer } & \text { : Did you often study calculus at home? } \\ \text { Student B } & \text { : I studied if I have calculus task. But, if } \\ & \text { there was no task, I would done another } \\ & \text { course's task. I do not like mathematics } \\ & \text { since junior high school. In fact, I did not } \\ & \text { want to joint Science major. I wanted to } \\ & \text { joint health education but I could not } \\ & \text { because my parents did not allow it. } \\ \text { Lecturer } & \text { : So, you do not motivation to study in this } \\ & \text { major? } \\ \text { Student B } & \text { : Yes Mam. } \\ \text { Lecturer } & \text { : How about study to prepare exam? Did } \\ & \text { you do that? } \\ \text { Student B } & \text { : I studied before exam. } \\ \text { Lecturer } & \text { : Although you do not really liked } \\ & \text { mathematics, but you studied calculus at } \\ & \text { home and prepared for exam. So, you } \\ & \text { could pass calculus course but you could } \\ & \text { not get good mark. }\end{array}$

The transcript above showed student had no good motivation intrinsic but she or he could pass the calculus course because she or he also studied hard calculus at home. It was also found that she or he did not understand was monotonicity and concavity of function and technique of integration. There were a number of students had the marks as same as Student B. They passed the calculus course but they did not get good mark. They just had the goal to pass the calculus course.

There was another transcript of interview with student who failed in calculus course. She or he had to take calculus course again in her/his second year.

\begin{tabular}{|c|c|}
\hline Lecturer & $\begin{array}{l}\text { : In mid semester exam, what topic that } \\
\text { you did not understand? }\end{array}$ \\
\hline Student C & : I forgot the problems, Mam. \\
\hline Lecturer & $\begin{array}{l}\text { : Okay, this is calculus problems sheet of } \\
\text { mid semester exam. What question that } \\
\text { you did not understand? }\end{array}$ \\
\hline Student C & : This, this, this, and this \\
\hline Lecturer & : What topic is that? \\
\hline Student C & : I do not know Miss. \\
\hline Lecturer & $\begin{array}{l}\text { : It is called inequality. You did not know } \\
\text { the name of the topic so you did not } \\
\text { understand the concept of the topic. } \\
\text { When I gave exercise in class, can you } \\
\text { solve the problem? }\end{array}$ \\
\hline Student C & : Yes, I can solve it. \\
\hline Lecturer & $\begin{array}{l}\text { : So, why you could not answer the } \\
\text { problem in exam? }\end{array}$ \\
\hline Student C & $\begin{array}{l}\text { I could not answer the problem because it } \\
\text { was different from the examples that } \\
\text { Mam give in class. }\end{array}$ \\
\hline Lecturer & $\begin{array}{l}\text { : Oh, so you only memorize the procedure } \\
\text { in examples? }\end{array}$ \\
\hline Student C & : Yes, Mam. \\
\hline Lecturer & : Did you study calculus at home? \\
\hline Student C & : No, Miss. \\
\hline Lecturer & $\begin{array}{l}\text { : How about mid semester and final } \\
\text { semester exam? Did you study to prepare } \\
\text { it? }\end{array}$ \\
\hline
\end{tabular}


Student C : Yes, Miss. I read the examples that Miss gave in classroom?

Lecturer : Only read it? Did you try to solve it?

Student C : No, Mam.

There were many information could be taken from transcript. It showed that student did not have motivation to study calculus. She or he did not study calculus at home at only memorized the procedure without understand the concepts. She or he failed in calculus course because got bad mark and there a number of students had the same mark too.

Analyzing of instruments found that students who had good intrinsic motivation would get good result in calculus course. They had positive attitudes toward mathematics. Attitudes towards mathematics had positive relation with motivation [7]. If students had positive attitudes towards mathematics, they could be motivated to study calculus hard and they would get good mark. If students had motivation, they would try to understand the concepts and have the courage to ask someone if they did not understand. The transcript also showed that students only memorized the procedure to solve the problem. They did not understand the concepts. That behavior would make them got misconception in calculus concepts [8]. Their behavior came from they were still students in high school. Mathematics was taught by giving students "nice" examples that can be solve by using simple procedure and the question in exam were always had same pattern with examples. So, they thought that they just need to memorize the procedure to solve the problem [9]. That's why student only read the book and did not do exercise when they would take exam. That behavior also made students did not have basic mathematics concepts. It made students found difficulty to understand calculus concepts [10].

\section{CONCLUSION}

Based on data analysis by using qualitative approach, it can be conclude that the problems in calculus learning are : (1) students do not have intrinsic motivation; (2) students only memorizing procedure to solve problem in calculus but they do not understand the concepts; (3) students do not have good foundations of mathematics concepts from high school;
(4) students do not have regular schedule to study calculus outside the classroom; and (5) students do not have courage to ask someone if they do not understand calculus.

That result shows that many cause of problems in calculus learning come from student internal factor. But, that does not mean teachers and lecturers cannot solve the problems. Innovative approach in calculus learning is needed to minimize the problems. So, it will get good result in calculus learning.

\section{REFERENCES}

[1] Albalawi, A. S., "The Effect of Using Flipped Classroom in Teaching Calculus on Students' Achievement at University of Tabuk". in International Journal of Research in Education and Science (IJRES), vol. 4, issue 1, 2018, pp. 198-207.

[2] Salleh, T. S. and Zakaria, E, Enhancing Students' Understanding in Integral Calculus Through the Integration of Maple in Learning”. in Procedia-Social and Behavioral Science 102, 2013, pp.204-211.

[3] Vinsonhaler, R., "Teaching Calculus with Infinesimals," in Journal of Humanistics Mathematics, vol. 6, issue 1, 2016, pp. 240-276.

[4] Ellis, J., Rasmussen, C.m and Duncan, K., "Switcher and Persister Experiences in Calculus I," in Sixteenth Annual Conference on Research in Undergraduate Mathematics Educations.

[5] Adhabi, E. and Anozie, C. B., "Literature Review for the Type of Interview in Qualitative Research," in International Journal of Education, Vol.9, No.3, 2017, pp. 86-97.

[6] Alshenqeeti, H., "Interviewing as a Data Collection Metheod: a Critical Review," in English Linguistic Research, Sciedu Press, Vol. 3, No. 1, 2014, pp. 39-45.

[7] Colomeischi, A. A. and Colomeischi, T., "The Students' Emotional Life and Their Attitudes Towards Mathematics Learning," in Procedia - Social and Behavioral Science 180, 2015, pp. 744-750.

[8] Klymchuk, S., "Using Counter-Examples in Teaching \& Learning Calculus: Studnets' Attitudes and Performance," in Mathematics Teaching-Research Journal Online, Vol. 5, No. 4, pp. 1-29.

[9] Tarmizi, R. A., "Visualizing Students' Difficulties in Learning Calculus," in Procedia - Social and Behavioral Science 8, 2010, pp. 377-383.

[10] Zakaria, E. and Salleh, T. S., "Using Technology in Leaning Integral Calculus," in Mediterranean Journal of Social Science, Vol. 6, No. 5, pp. 144-148. 